\title{
TEN BADLY EXPLAINED TOPICS IN MOST CORPORATE FINANCE BOOKS
}

\author{
Pablo Fernández
}


The CIIF, International Center for Financial Research, is an interdisciplinary center with an international outlook and a focus on teaching and research in finance. It was created at the beginning of 1992 to channel the financial research interests of a multidisciplinary group of professors at IESE Business School and has established itself as a nucleus of study within the School's activities.

Ten years on, our chief objectives remain the same:

- Find answers to the questions that confront the owners and managers of finance companies and the financial directors of all kinds of companies in the performance of their duties

- Develop new tools for financial management

- Study in depth the changes that occur in the market and their effects on the financial dimension of business activity

All of these activities are programmed and carried out with the support of our sponsoring companies. Apart from providing vital financial assistance, our sponsors also help to define the Center's research projects, ensuring their practical relevance.

The companies in question, to which we reiterate our thanks, are:

Aena, A.T. Kearney, Caja Madrid, Fundación Ramón Areces, Grupo Endesa, Royal Bank of Scotland and Unión Fenosa.

http://www.iese.edu/ciif/ 


\title{
TEN BADLY EXPLAINED TOPICS IN MOST CORPORATE FINANCE BOOKS
}

\author{
Pablo Fernández ${ }^{1}$
}

\section{Abstract}

This paper addresses 10 corporate finance topics that are not well treated (or not treated at all) in many Corporate Finance Books.

The topics are: 1. Where does the WACC equation come from? 2. The WACC is not a cost. 3. What is the WACC equation when the value of the debt is not equal to its nominal value? 4 . The term equity premium is used to designate four different concepts. 5. Textbooks differ a lot on their recommendations regarding the equity premium. 6. Which Equity Premium is used by professors, analysts and practitioners? 7. Calculated (historical) betas change dramatically from one day to the next. 8. Why do many professors still use calculated (historical) betas in class? 9. EVA does not measure Shareholder value creation. 10. The relationship between the WACC and the value of the tax shields (VTS).

JEL Classification: G12, G31, M21

Keywords: WACC, beta, equity premium, EVA, value of tax shields, required return to equity.

\footnotetext{
${ }^{1}$ Professor, Financial Management, PricewaterhouseCoopers Chair of Finance, IESE
} 


\section{TEN BADLY EXPLAINED TOPICS IN MOST CORPORATE FINANCE BOOKS}

\section{Where does the WACC equation come from?}

The WACC is the rate at which the Free Cash Flows (FCF) must be discounted to obtain the same result as the valuation using Equity Cash Flows.

There are two basic methods for valuing companies by discounted cash flows:

Method 1. Using the expected equity cash flow (ECF) and the required return to equity (Ke).

Equation [1] indicates that the value of the equity (E) is the present value of the expected equity cash flows (ECF) discounted at the required return to equity (Ke).

[1]

$$
\mathrm{E}_{0}=\mathrm{PV}_{0}\left[\mathrm{Ke}_{\mathrm{t}} ; \mathrm{ECF}_{\mathrm{t}}\right]
$$

Equation [2] indicates that the value of the debt (D) is the present value of the expected debt cash flows (CFd) discounted at the required return to debt (Kd).

[2]

$$
\mathrm{D}_{0}=\mathrm{PV}_{0}\left[\mathrm{Kd}_{\mathrm{t}} ; \mathrm{CFd} \mathrm{d}_{\mathrm{t}}\right]
$$

The free cash flow is the hypothetical equity cash flow when the company has no debt. The expression that relates the FCF (Free Cash Flow) with the ECF is:

[3]

$$
\mathrm{ECF}_{\mathrm{t}}=\mathrm{FCF}_{\mathrm{t}}+\Delta \mathrm{D}_{\mathrm{t}}-\mathrm{I}_{\mathrm{t}}(1-\mathrm{T})
$$

$\Delta \mathrm{D}_{\mathrm{t}}$ is the increase in debt, and $\mathrm{I}_{\mathrm{t}}$ is the interest paid by the company. $\mathrm{CFd}_{\mathrm{t}}=\mathrm{I}_{\mathrm{t}}-\Delta \mathrm{D}_{\mathrm{t}}$

Method 2. Using the free cash flow and the WACC (weighted average cost of capital).

Equation [4] indicates that the value of the debt (D) plus that of the shareholders' equity (E) is the present value of the expected free cash flows (FCF) that the company will generate, discounted at the weighted average cost of capital (WACC):

[4]

$$
\mathrm{E}_{0}+\mathrm{D}_{0}=\mathrm{PV}_{0}\left[\mathrm{WACC}_{\mathrm{t}} ; \mathrm{FCF}_{\mathrm{t}}\right]
$$


The WACC is the rate at which the FCF must be discounted so that equation [4] gives the same result as that given by the sum of [1] and [2]. By doing so (see Exhibit 1), the expression of the WACC (Weighted Average Cost of Capital) is given by [5]:

$$
\text { WACC }_{t}=\frac{E_{t-1} K_{t}+D_{t-1} K_{t}(1-T)}{E_{t-1}+D_{t-1}}
$$

$\mathrm{T}$ is the effective tax rate applied to interest in equation [3].

$\mathrm{E}_{\mathrm{t}-1}+\mathrm{D}_{\mathrm{t}-1}$ are not market values nor book values: in actual fact, $\mathrm{E}_{\mathrm{t}-1}$ and $\mathrm{D}_{\mathrm{t}-1}$ are the values obtained when the valuation is performed using formulae [1], [2] or [4]. ${ }^{1}$

This is explained in the article

“WACC: Definition, Misconceptions and Errors”, downloadable at http://ssrn.com/abstract=1620871. Also in "Valuing Companies by Cash Flow Discounting: Ten Methods and Nine Theories", downloadable at http://ssrn.com/abstract=256987.

\section{The WACC is not a cost}

Just by looking at equation [5], it is clear that the WACC is neither a cost nor a required return. The WACC is a weighted average of a cost $(\mathrm{Kd})$ and a required return $(\mathrm{Ke})$.

The WACC is a weighted average of two very different magnitudes:

- a cost: the cost of debt $(\mathrm{Kd})$, and

- a required return: the required return to equity (Ke). Although Ke is often called the cost of equity, there is a big difference between a cost and a required return.

So the WACC is neither a cost nor a required return, but a weighted average of a cost and a required return.

To refer to the WACC as the "cost of capital" may be misleading because it is not a cost.

\section{What is the WACC equation when the value of debt is not equal to its nominal value?}

When the required return to debt $(\mathrm{Kd})$ is different from the cost of the debt (r), the value of debt (D) is not equal to its nominal value (N).

The interest paid in period $t$ is: $I_{t}=N_{t-1} r_{t}$.

\footnotetext{
${ }^{1}$ Consequently, the valuation is an iterative process: the free cash flows are discounted at the WACC to calculate the company's value $(\mathrm{D}+\mathrm{E})$ but, in order to obtain the WACC, we need to know the company's value (D+E). 
The expression of the WACC in this case is: [5*]

$$
\mathrm{WACC}=\frac{\mathrm{EKe}+\mathrm{D} \mathrm{Kd}-\mathrm{NrT}}{\mathrm{E}+\mathrm{D}}
$$

The increase in debt in period $t$ is: $\Delta \mathrm{N}_{\mathrm{t}}=\mathrm{N}_{\mathrm{t}}-\mathrm{N}_{\mathrm{t}-1}$.

The debt cash flow in period $t$ is: $\mathrm{CFd}_{\mathrm{t}}=\mathrm{I}_{\mathrm{t}}-\Delta \mathrm{N}_{\mathrm{t}}=\mathrm{N}_{\mathrm{t}-1} \mathrm{r}_{\mathrm{t}}-\left(\mathrm{N}_{\mathrm{t}}-\mathrm{N}_{\mathrm{t}-1}\right)$.

This is explained in the article "Valuing Companies by Cash Flow Discounting: Ten Methods and Nine Theories", downloadable at http://ssrn.com/abstract=256987.

\section{The term equity premium is used to designate four different concepts}

The equity premium (also called market risk premium, equity risk premium, market premium and risk premium), is one of the most important and most discussed but elusive parameters in finance.

Part of the confusion arises from the fact that the term equity premium is used to designate four different concepts:

1. Historical equity premium (HEP): historical differential return of the stock market over treasuries.

2. Expected equity premium (EEP): expected differential return of the stock market over treasuries.

3. Required equity premium (REP): incremental return of a diversified portfolio (the market) over the risk-free rate required by an investor. It is used for calculating the required return to equity.

4. Implied equity premium (IEP): the required equity premium that arises from assuming that the market price is correct.

The equity premium designates four different concepts: Historical Equity Premium (HEP); Expected Equity Premium (EEP); Required Equity Premium (REP); and Implied Equity Premium (IEP). Although the HEP is equal for all investors, the REP, the EEP and the IEP are different for different investors.

There is a rather schizophrenic approach to valuation: while all authors admit different expectations of equity cash flows, most authors look for a single discount rate. It seems as if the expectations of equity cash flows are formed in a democratic regime, while the discount rate is determined in a dictatorship.

A single IEP requires assuming homogeneous expectations for the expected growth (g), but we show that there are several pairs (IEP, g) that satisfy current prices. We claim that different investors have different REPs and that it is impossible to determine the REP for the market as a whole, because it does not exist. 
129 of the 150 books identify Expected and Required equity premium and 82 identify Expected and Historical equity premium.

This is explained in the article "Equity Premium: Historical, Expected, Required and Implied", downloadable at http://ssrn.com/abstract=933070.

\section{Textbooks differ a lot on their recommendations regarding the equity premium}

The article "The Equity Premium in 150 Textbooks"2 reviews 150 textbooks on corporate finance and valuation published between 1979 and 2009 by authors such as Brealey, Myers, Copeland, Merton, Ross, Bruner, Bodie, Penman, Arzac, Damodaran... and shows that their recommendations regarding the equity premium range from 3\% to 10\%, and that 51 books use different equity premia in different pages. The 5-year moving average has declined from 8.4\% in 1990 to $5.7 \%$ in 2008 and 2009.

Figure 1 contains the evolution of the Required Equity Premium (REP) used or recommended by 150 books, and helps to explain the confusion that many students and practitioners have about the equity premium. The average is $6.5 \%$. Figure 2 shows that the 5 -year moving average has declined from 8.4\% in 1990 to 5.7\% in 2008 and 2009.

\section{Figure 1}

Evolution of the Required Equity Premium (REP) used or recommended in 150 finance and valuation textbooks

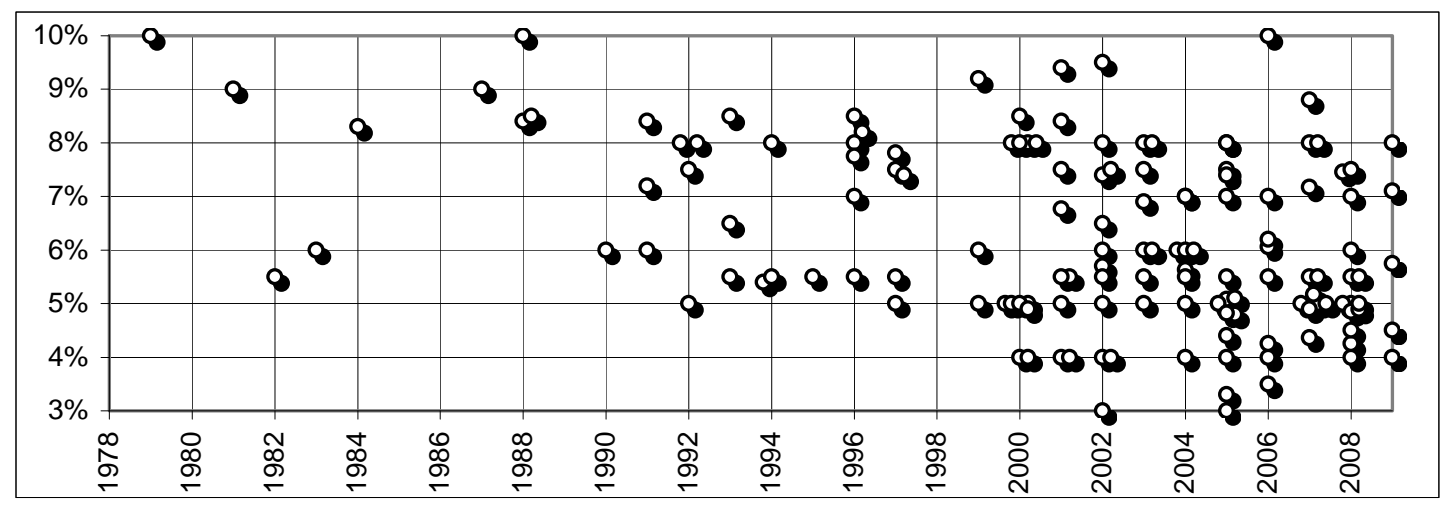

\footnotetext{
${ }^{2}$ Downloadable at: http://ssrn.com/abstract=1473225. 


\section{Figure 2}

Moving average (last 5 years) of the REP used or recommended in 150 finance and valuation textbooks

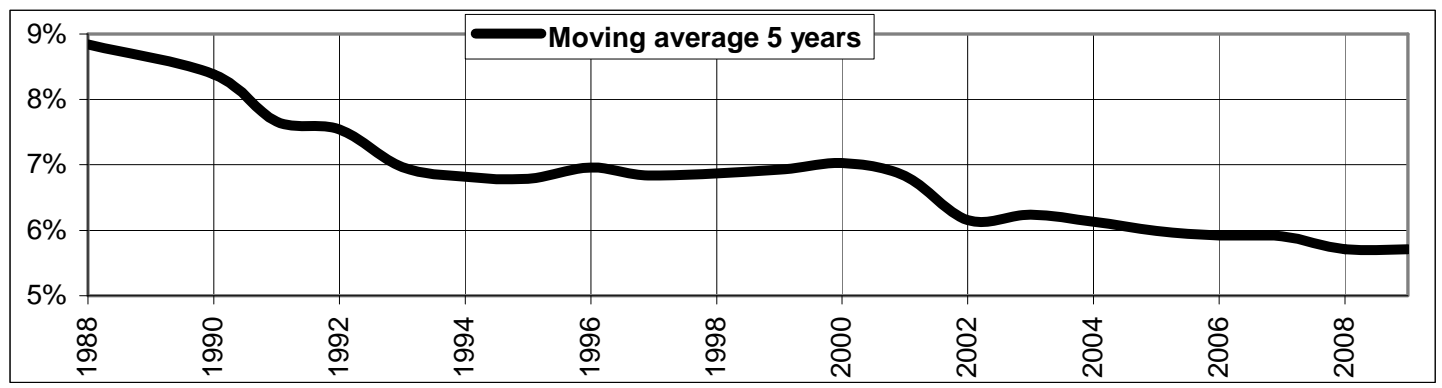

For example, Brealey and Myers considered until 1996 that REP $=$ EEP $=$ arithmetic HEP over T-Bills according to Ibbotson: 8.3\% in 1984 and 8.4\% in 1988, 1991 and 1996. But in 2000 and 2003, they stated that "Brealey and Myers have no official position on the exact market risk premium, but we believe a range of 6 to $8.5 \%$ is reasonable for the United States." In 2005, they increased that range to "5 to 8 percent."

Copeland et al. (1990 and 1995), authors of the McKinsey book on valuation, advised using a REP = geometric HEP versus Government T-Bonds, which were 6\% and 5.5\% respectively. However, in 2000 and 2005, they changed criteria and advised using the arithmetic ${ }^{3}$ HEP of 2year returns versus Government T-Bonds reduced by a survivorship bias. In 2000, they recommended $4.5-5 \%$ and in 2005, they used a REP of $4.8 \%$ because "we believe that the market risk premium as of year-end 2003 was just under 5\%."

\section{Which Equity Premium do professors, analysts and practitioners use?}

A survey ${ }^{4}$ shows that the average Market Risk Premium (MRP) used in 2011 by professors for the USA (5.7\%) is higher than that used by analysts (5.0\%) and companies (5.6\%). The standard deviation of the MRP used in 2011 by analysts (1.1\%) is lower than that used by companies $(2.0 \%)$ and professors (1.6\%).

Figure 3 shows the dispersion of the MRP used.

3 Although in the 2nd edition they stated (page 268): "we use a geometric average of rates of return because arithmetic averages are biased by the measurement period."

4 "US Market Risk Premium Used in 2011: A Survey", downloadable at: http://ssrn.com/abstract=1805852. Also: "Market Risk Premium Used in 56 Countries in 2011: A Survey with 6,014 Answers", downloadable at: http://ssrn.com/abstract=1822182. 


\section{Figure 3}

Market Risk Premium for the USA used in 2011
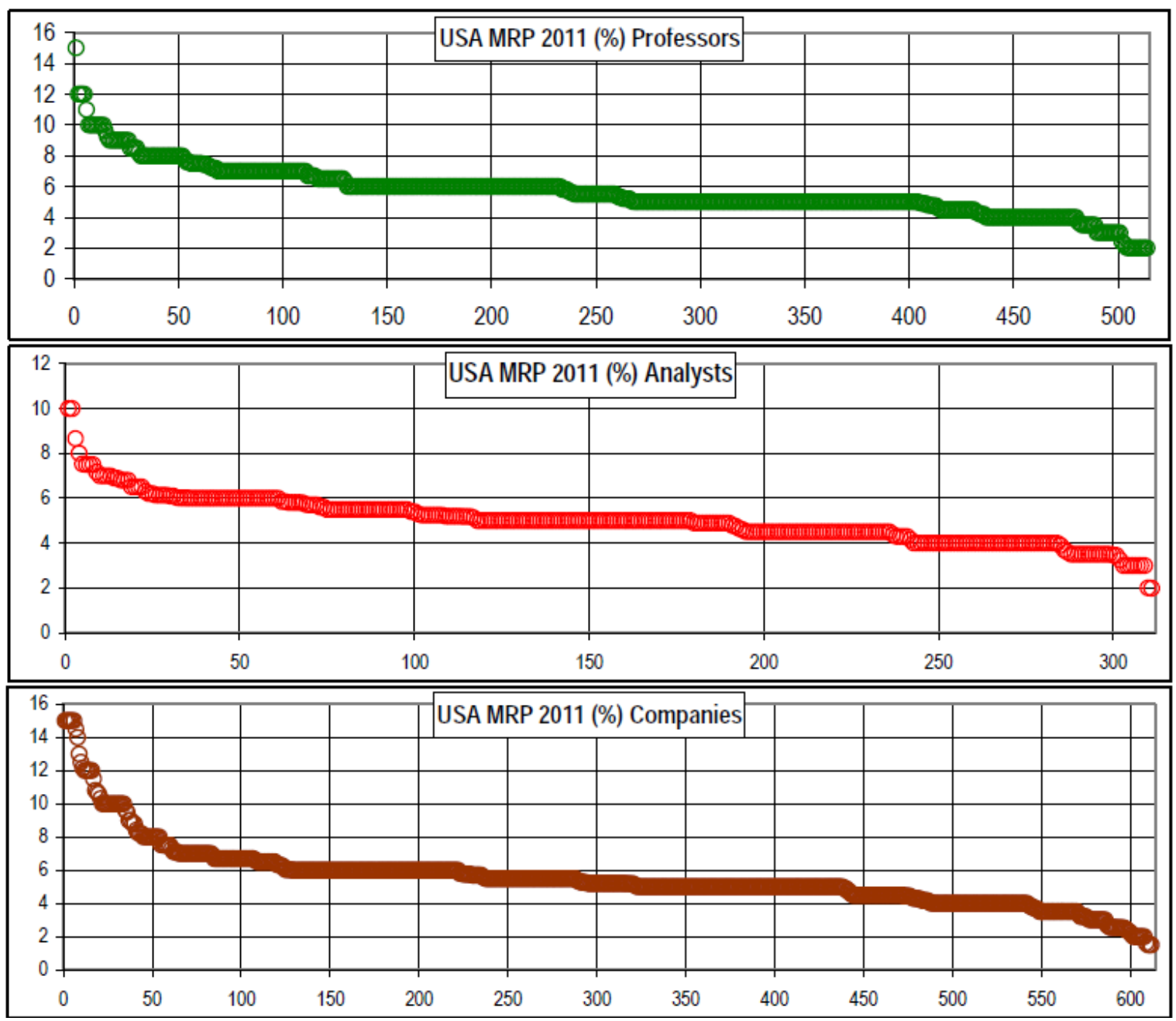

\begin{tabular}{lrrrrrrrrr}
\hline & \multicolumn{2}{c}{ Professors } & & \multicolumn{2}{c}{ Analyst } & & \multicolumn{2}{c}{ Companies } \\
\cline { 2 - 3 } \cline { 9 - 10 } (\%) & $\mathbf{2 0 1 1}$ & $\mathbf{2 0 1 0}$ & & $\mathbf{2 0 1 1}$ & $\mathbf{2 0 1 0}$ & & $\mathbf{2 0 1 1}$ & $\mathbf{2 0 1 0}$ \\
\hline Average & 5.7 & 6.0 & & 5.0 & 5.1 & & 5.6 & 5.3 \\
St. Dev. & 1.6 & 1.7 & & 1,1 & 1.1 & & 2.0 & 1.8 \\
MAX & 15.0 & 12.0 & & 10.0 & 10.0 & & 15.0 & 11.2 \\
Median & 5.5 & 6.0 & & 5.0 & 5.0 & & 5.2 & 5.0 \\
Min & 2.0 & 2.0 & & 2.0 & 20.5 & & 1.5 & 1.9 \\
Number of answers & 514 & 462 & & 311 & 104 & & 613 & 205 \\
\hline
\end{tabular}




\section{Calculated (historical) betas change dramatically from one day to the next}

Figure 3 shows the historical betas of AT\&T, Boeing and Coca-Cola in the two-month period of December 2001 and January 2002 with respect to the S\&P 500. It may be seen that the beta of AT\&T varies from 0.32 (January 14, 2002) to 1.02 (December 27, 2001), the beta of Boeing varies from 0.57 (January 30, 2002) to 1.22 (January 20, 2002), and the beta of Coca-Cola varies from 0.55 (December 28, 2001) to 1.11 (January 15, 2002). A closer look at the data shows that the beta of AT\&T is higher than the beta of Boeing on 32\% of the days, and is higher than the beta of Coca-Cola on $50 \%$ of the days. The beta of Boeing is higher than the beta of Coca-Cola on 76\% of the days. AT\&T has the maximum beta (of the three companies) on $29 \%$ of the days and the minimum beta on $47 \%$ of the days. Boeing has the maximum beta (of the three companies) on 58\% of the days and the minimum beta on 15\% of the days. CocaCola has the maximum beta (of the three companies) on 13\% of the days and the minimum beta on $38 \%$ of the days.

\section{Figure 4}

Historical betas of AT\&T, Boeing and Coca-Cola

Betas calculated during the two-month period of December 2001 and January 2002 with respect to the S\&P 500. Each day, betas are calculated using 5 years of monthly data, i.e. on December 18, 2001, the beta is calculated by running a regression of the 60 monthly returns of the company on the 60 monthly returns of the S\&P 500. The returns of each month are calculated on the $18^{\text {th }}$ of the month:

$$
\text { monthly return of December 18, 2001 }=\frac{\text { total return December 18, } 2001}{\text { total return November 18, } 2001}-1
$$

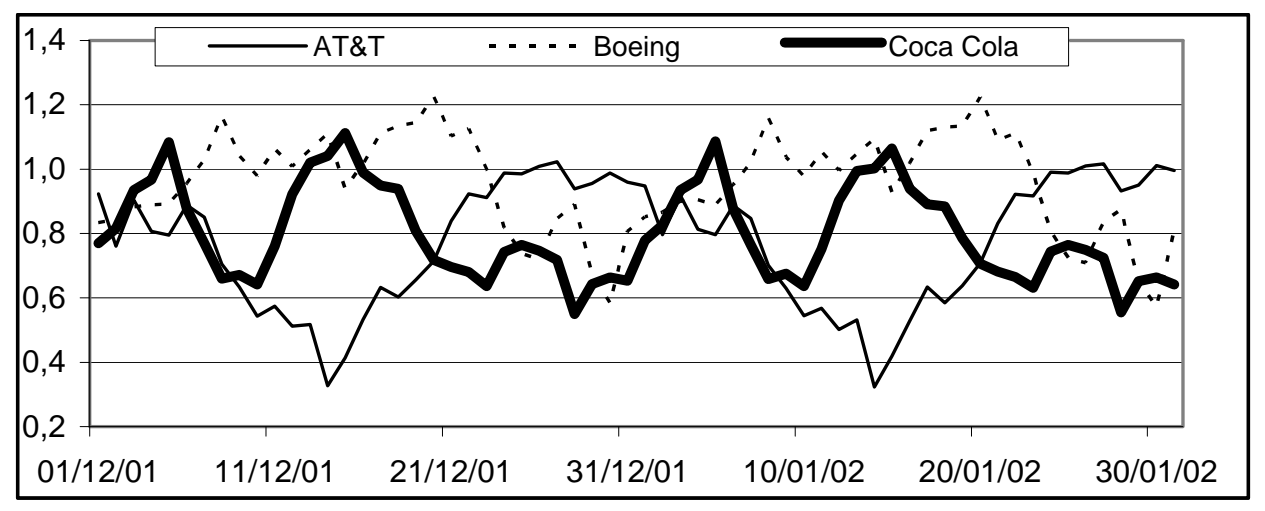

This is explained in the article "Are Calculated Betas Worth for Anything?", downloadable at http://ssrn.com/abstract=504565.

The article provides additional information about the 62 calculated betas of 3,813 companies with respect to the S\&P 500 in the two-month period of December 2001 and January 2002:

In the sample period, 2,927 companies (77\%) had a maximum beta more than two times bigger than their minimum beta. 
Only 2,780 companies (73\%) had positive betas on the 62 consecutive days.

$52 \%$ of the companies in the S\&P 500 had a maximum beta more than two times bigger than their minimum beta.

The median of the difference between the maximum and the minimum of the 62 betas calculated for each company was 0.88 for the 3,813 companies in our full sample, 0.63 for the 450 companies in the $\mathrm{S} \& \mathrm{P} 500$.

Looking at industry betas, $25 \%$ of the industries had a maximum beta more than two times bigger than their minimum beta.

Therefore, it may be an enormous error to use the historical beta as a proxy for the expected beta. First, because it is almost impossible to calculate a meaningful beta because historical betas change dramatically from one day to the next; second, because very often we cannot say with a relevant statistical confidence that the beta of one company is smaller or bigger than the beta of another; third, because historical betas do not make much sense in many cases: highrisk companies very often have smaller historical betas than low-risk companies; fourth, because historical betas depend very much on which index we use to calculate them.

\section{Why do many professors still use calculated (historical) betas in class?}

A survey ${ }^{5}$ performed in 2009 reports 2,510 answers from professors from 65 countries and 934 institutions. 1,791 respondents use betas, but 107 of them do not justify the betas they use.

97.3\% of the professors that justify the betas use regressions, websites, databases, textbooks or papers (the paper specifies which ones), although many of them state that calculated betas "are poorly measured and have many problems".

Only $0.9 \%$ of the professors justify the beta using exclusively personal judgement (named qualitative, common sense, intuitive, and logical magnitude betas by different professors).

All professors admit that different investors may have different expected cash flows, but many of us affirm that the required return should be equal for everybody: That is a kind of schizophrenic approach to valuation. Most professors teach that the expected cash flows should be computed using common sense and good judgement about the company, its industry, the national economies... However, many professors teach a formula to calculate the discount rate (instead of using again common sense).

\footnotetext{
5 “Betas Used by Professors: A Survey with 2,500 Answers”, downloadable at http://ssrn.com/abstract=1407464. 
The paper includes interesting comments such as:

- I justify the betas by computing them and proving that they are right. References are also made to financial websites.

- I always emphasize that beta calculations have to be taken with some leeway.

- I use betas... but I use all metrics that are available.

- I do not have much confidence in the beta but we don't seem to have any easy substitute.

- It is poorly measured, but no substitution so far.

- I justify the betas if the published betas are "abnormal" (i.e., negative when you would expect it to be positive)

- The model has received a Nobel Prize in Economics and while not perfect, it is used extensively in practice.

- If you don't use betas, how do you adjust for risk? Almost every practitioner book uses betas such as the McKinsey publications.

- I use whatever is suggested in the teaching note.

- Beta is a simple method and it is used in the "real world." It is really not that helpful, but it is easy to use.

- I use beta in my valuations. In consulting, it is essential to fully support your estimates.

- Referees want to see them as the underlying model. I need a model anyway, and these are the safe bets that referees will not challenge.

- Students tend so see CAPM as just one recipe from a cooking book.

- I do not use betas except for teaching purposes. I researched the predictability for stock returns. I found worse out of sample predictive power for future returns using betas than when the market average return is used.

- We justify use of betas through underlying theory and students are convinced. I found that students are quite excited about betas. 


\section{EVA does not measure Shareholder value creation ${ }^{6}$}

EVA $^{\mathrm{TM}}$ (economic value added) is the term used ${ }^{7}$ to define:

$\mathrm{EVA}_{\mathrm{t}}=\mathrm{NOPAT}_{\mathrm{t}}-\left(\mathrm{D}_{\mathrm{t}-1}+\mathrm{Ebv}_{\mathrm{t}-1}\right) \mathrm{WACC}$

EVA is simply the NOPAT less the firm's book value $\left(\mathrm{D}_{\mathrm{t}-1}+\mathrm{Ebv}_{\mathrm{t}-1}\right)$ multiplied by the average cost of capital (WACC). NOPAT (net operating profit after taxes) is the profit of the unlevered (debt-free) firm. Sometimes, it is also called EBIAT (earnings before interest and after tax) ${ }^{8}$.

Stern Stewart \& Co’s advertising contained such eye-catching statements as the following:

- "EVA is the measure that correctly takes into account value creation or destruction in a company".

- "EVA is a measure of the true financial performance of a company".

- "There is evidence that increasing EVA is the key for increasing the company's value creation".

- "more EVA always is unambiguously better for shareholders".

- "managing for higher EVA is, by definition, managing for a higher stock price".

- "EVA is the performance measure most directly linked to the creation of shareholder wealth over time".

However, accounting-based measures cannot measure value creation

A firm's value and the increase in the firm's value over a certain period are basically determined by the changes in expectations regarding the growth of the firm's cash flows and also by the changes in the firm's risk, which lead to changes in the discount rate. However, accounting only reflects the firm's history. Both the items of the income statement, which explain what has happened during a certain year, and those of the balance sheet, which reflect the state of a firm's assets and liabilities at a certain point in time, are historic data. Consequently, it is impossible for accounting-based measures, such as EVA, to measure value creation.

It is simple to verify this statement in quantitative terms: one has only to analyze the relationship between the shareholder value creation, or the shareholder value added, and the EVA and cash value added.

\footnotetext{
${ }^{6}$ This is explained in the article "EVA and Cash Value Added Do Not Measure Shareholder Value Creation", downloadable at http://ssrn.com/abstract=270799.

7 According to Stern Stewart \& Co's definition. See page 192 of their book The Quest for Value. The EVA Management Guide.

${ }^{8}$ NOPAT is also called NOPLAT (Net Operating Profit Less Adjusted Taxes). See, for example, Copeland, Koller and Murrin (2000). 
Using EVA, MVA, NOPAT and WACC data provided by Stern Stewart for 582 companies, it is easy to calculate the 10-year correlation between the increase in the MVA (Market Value Added) each year and each year's EVA, NOPAT and WACC:

- For 210 companies (out of the 582) the correlation with the EVA was negative!

- The average correlation between the increase in the MVA and EVA, NOPAT and WACC was $16 \%, 21 \%$ and $-21.4 \%$.

- The average correlation between the increase in the MVA and the increases of EVA, NOPAT and WACC was $18 \%, 22.5 \%$ and $-4.1 \%$.

\section{The relationship between the WACC and the value of the tax shields (VTS)}

The correct calculation of the WACC rests on a correct valuation of the tax shields. The value of tax shields depends on the company's debt policy.

The equation that relates the WACC and the VTS (the Value of Tax Shields) for a perpetuity (being $g$ the growth rate) is:

$$
W A C C=\operatorname{Ku}\left(1-\frac{V T S}{E+D}\right)+\frac{g \text { VTS }}{E+D}
$$

And the relationship between $\mathrm{Ke}$ and $\mathrm{Ku}$ is:

$$
\mathrm{Ke}=\mathrm{Ku}+\frac{\mathrm{D}}{\mathrm{E}}[K u-K d(1-T)]-\frac{V T S}{E}(K u-g)
$$

Ke is the required return to equity,

$\mathrm{Kd}$ is the cost of the debt,

$\mathrm{Ku}$ is the required return to equity in the debt-free company (also called the required return to assets),

$\mathrm{T}$ is the effective tax rate applied to earnings,

$\mathrm{D}$ is the value of the debt and $\mathrm{E}$ is the value of the equity.

9 This is explained in the article "A General Formula for the WACC: A Correction", downloadable at http://ssrn.com/abstract=949464. 


\section{Exhibit 1}

Calculating the WACC

The intertemporal form of equations [1], [2] and [4] is:

[1i] $\quad \mathrm{E}_{\mathrm{t}+1}=\mathrm{E}_{\mathrm{t}}\left(1+\mathrm{Ke}_{\mathrm{t}+1}\right)-\mathrm{ECF}_{\mathrm{t}+1}$

[2i] $\quad \mathrm{D}_{\mathrm{t}+1}=\mathrm{D}_{\mathrm{t}}\left(1+\mathrm{Kd}_{\mathrm{t}+1}\right)-\mathrm{CFd}_{\mathrm{t}+1}$

$[4 \mathrm{i}] \quad\left[\mathrm{E}_{\mathrm{t}+1}+\mathrm{D}_{\mathrm{t}+1}\right]=\left[\mathrm{E}_{\mathrm{t}}+\mathrm{D}_{\mathrm{t}}\right]\left(1+\mathrm{WACC}_{\mathrm{t}+1}\right)-\mathrm{FCF}_{\mathrm{t}+1}$

The sum of [1i] and [2i] must be equal to [4i]:

$$
\begin{aligned}
& {\left[\mathrm{E}_{\mathrm{t}}+\mathrm{D}_{\mathrm{t}}\right]+\mathrm{E}_{\mathrm{t}} \mathrm{Ke}_{\mathrm{t}+1}+\mathrm{D}_{\mathrm{t}} \mathrm{Kd}_{\mathrm{t}+1}-\left[\mathrm{ECF}_{\mathrm{t}+1}+\mathrm{CFd}_{\mathrm{t}+1}\right]=\left[\mathrm{E}_{\mathrm{t}}+\mathrm{D}_{\mathrm{t}}\right]\left(1+\mathrm{WACC}_{\mathrm{t}+1}\right)-\mathrm{FCF}_{\mathrm{t}+1}} \\
& \text { As } \mathrm{CFd}_{\mathrm{t}+1}=\mathrm{D}_{\mathrm{t}} \mathrm{Kd}_{\mathrm{t}+1}-\left[\mathrm{D}_{\mathrm{t}+1}-\mathrm{D}_{\mathrm{t}}\right] \text { and } \mathrm{ECF}_{\mathrm{t}+1}=\mathrm{FCF}_{\mathrm{t}+1}+\left[\mathrm{D}_{\mathrm{t}+1}-\mathrm{D}_{\mathrm{t}}\right]-\mathrm{D}_{\mathrm{t}} \mathrm{Kd}_{\mathrm{t}+1}(1-\mathrm{T}) \\
& {[\mathrm{ECFt}+1+\mathrm{CFdt}+1]=\mathrm{FCFt}+1+\mathrm{Dt} \mathrm{Kdt+1}-\mathrm{Dt} \mathrm{Kdt+1}(1-\mathrm{T})}
\end{aligned}
$$

and

$[\mathrm{Et}+\mathrm{Dt}]+\mathrm{Et} \mathrm{Ket+1}+\mathrm{Dt} \mathrm{Kdt+1}(1-\mathrm{T})]-\mathrm{FCFt}+1=[\mathrm{Et}+\mathrm{Dt}](1+\mathrm{WACC}+1)-\mathrm{FCFt}+1$

$[\mathrm{Et}+\mathrm{Dt}] \mathrm{WACC}+1=\mathrm{Et} \mathrm{Ket}+1+\mathrm{Dt} \mathrm{Kdt+1}(1-\mathrm{T})$

The WACC is: WACC $_{t+1}=\frac{E_{t} K_{t+1}+D_{t} K_{t+1}(1-T)}{E_{t}+D_{t}}$

$T$ is the effective tax rate applied to interest in equation [3]. $E_{t}+D_{t}$ are not market values nor book values: in actual fact, $E_{t}$ and $D_{t}$ are the values obtained when the valuation is performed using formulae [1], [2] or [4]. 